\title{
Potensi Penggunaan Materi Genetik Fetus pada Sirkulasi Maternal untuk Diagnosis Prenatal Noninvasif Penyakit Genetik
}

\author{
Dewi Megawati ${ }^{1}$, Ita M. Nainggolan ${ }^{2,3}$, Agung Nova Mahendra ${ }^{4}$, Nanis S. Marzuki ${ }^{2,3}$ \\ ${ }^{I}$ Fakultas Kedokteran dan Ilmu Kesehatan Universitas Warmadewa, Denpasar \\ ${ }^{2}$ Lembaga Biologi Molekuler Eijkman, Jakarta \\ ${ }^{3}$ Kementrian Riset, Teknologi dan Pendidikan Tinggi, Jakarta \\ ${ }^{4}$ Fakultas Kedokteran Universitas Udayana, Denpasar \\ Email: dewimegawati.aa@gmail.com
}

\begin{abstract}
Abstrak
Diagnosis prenatal adalah teknik diagnostik untuk menentukan kondisi fetus yang belum lahir apakah memiliki kelainan genetik ataupun kelainan lainnya. Teknik ini umumnya dilakukan pada penyakit genetik yang tidak dapat diobati di mana terminasi menjadi bahan pertimbangan. Teknik ini juga dilakukan pada kasus yang memerlukan penanganan segera pada saat prenatal dan pada kondisi yang dapat menimbulkan morbiditas atau mortalitas pada ibu. Diagnosis prenatal dapat dilakukan melalui metode invasif dan noninvasif. Metode invasif seperti amniocentesis dan biopsi villi korialis (CVS) memiliki resiko menimbulkan kecacatan bahkan kematian fetus. Pendekatan nonivasif melalui ultrasonografi belum cukup akurat untuk diagnosis penyakit genetik, sehingga masih memerlukan pengambilan sampel fetus untuk menegakkan diagnosis. Pendekatan terbaru pengambilan sampel fetus secara noninvasif dilakukan melalui pengambilan sel fetus, DNA dan mRNA fetus yang terdapat dalam sirkulasi darah maternal. Pada artikel ini dipaparkan mengenai perkembangan riset, kendala, serta potensi aplikasi klinis ketiga metode pengambilan sampel fetus tersebut.
\end{abstract}

Kata kunci: diagnosis prenatal nonivasif, penyakit genetik, cell-free fetal DNA/mRNA, sel fetus

\section{Abstract}

\section{[Potential Use of Fetal Genetic Material in Maternal Circulation for Prenatal Noninvasive Diagnosis of Genetic Disease]}

Prenatal diagnostic technique is used to determine whether the unborn fetus is affected with a genetic disorder or other abnormality. This technique is generally carried out for a genetic disease that is not treatable, in which the termination should be considered. This technique is also performed in cases that require immediate action during the prenatal period and in conditions that can lead to morbidity or mortality of the mother. Prenatal diagnosis can be done by invasive and noninvasive methods. Invasive methods such as amniocentesis and chorionic villus sampling (CVS) have a risk of causing disability and even death of the fetus. While noninvasive approach by ultrasound is not sufficiently accurate for the diagnosis of genetic diseases, therefore further fetal sampling is required. Noninvasive prenatal diagnosis is a new type of genetic testing done through taking fetal cells, fetal DNA and $m R N A$, which are found in maternal blood circulation. In this review, we present development of research, constraints, and potential clinical applications of these three methods for noninvasive sampling of the fetus.

Keywords: noninvasive prenatal diagnosis, genetic disease, cell-free fetal DNA/mRNA, fetal cell

\section{LATAR BELAKANG}

Penyakit genetik adalah suatu kondisi yang disebabkan oleh kelainan salah satu/ lebih gen atau kromosom. Penyebab kelainan tersebut dapat berupa perubahan satu nukleotida pada gen, delesi besar pada kromosom serta kelainan jumlah atau struktur kromosom. Penyakit genetik dapat diklasifikasikan menjadi: penyakit monogen, penyakit poligen/multifaktorial, kelainan kromosom dan kelainan mitokondria. ${ }^{[1]}$ Sampai saat ini, belum ada tindakan kuratif yang memadai untuk mengatasi penyakit genetik. Tata laksana penyakit genetik pada umumnya hanya bersifat suportif dan simptomatik dengan pemberian terapi untuk mengurangi gejala klinis. Terapi gen pada penderita penyakit 
genetik masih belum dapat diaplikasikan secara luas karena hasil penelitian masih sangat bervariasi dan memerlukan biaya yang besar. Metode stem cell cukup mahal dan sangat memerlukan kecocokan human leukocyte antigen (HLA). Pada pasangan yang mempunyai resiko memiliki anak dengan penyakit genetik yang membahayakan fetus dan maternal, dapat dilakukan tindakan preventif baik berupa konseling genetik pranikah maupun diagnosis prenatal. ${ }^{[2]}$

Diagnosis prenatal dapat dilakukan melalui metode invasif dan noninvasif. Pendekatan noninvasif melalui ultrasonografi (USG) masih memerlukan prosedur lanjutan untuk memastikan diagnosis penyakit genetik, sehingga pengambilan sampel fetus tetap diperlukan untuk dianalisis lebih lanjut pada level molekuler. Sebagai contoh: kasus hydrops fetalis yang terdeteksi pada janin dengan USG memerlukan analisis lebih lanjut untuk memastikan penyebab hydrops. Pengambilan sampel fetus dapat dilakukan melalui metode invasif seperti pengambilan cairan amnion (amniocentesis) dan biopsi vili korialis (CVS/chorionic villus sampling). ${ }^{[3,4]}$

Pertimbangan metode yang digunakan untuk diagnosis prenatal didasarkan pada usia kehamilan. Seluruh prosedur pengambilan sampel fetus harus dilakukan oleh ahli fetomaternal dengan panduan USG kualitas tinggi. Biopsi vili korialis dilakukan dengan cara transervikal atau aspirasi abdominal pada usia kehamilan yang lebih dini, yaitu pada usia kehamilan 9 -11 minggu, namun biopsi villi korialis pada usia kurang dari 10 minggu menimbulkan risiko terjadinya malformasi, sehingga WHO menganjurkan untuk dilakukan setelah usia kehamilan 10 minggu. Resiko terjadinya abortus pada biopsi villi korialis sekitar 1-2\%, sedangkan tindakan amniocentesis, yaitu pengambilan cairan amnion yang umumnya efektif dilakukan pada usia kehamilan 16-22 minggu, memiliki resiko abortus lebih kecil yaitu $0,5 \% .{ }^{[3]}$ Pengambilan sampel fetus melalui amniocentesis memiliki beberapa kendala seperti: letak plasenta di anterior, kehamilan ganda, oligohidramnion dan ibu dengan obesitas. ${ }^{\left[{ }^{3}\right]}$

DNA fetus dapat diisolasi dari $20 \mathrm{mg}$ villi korialis atau $15 \mathrm{~mL}$ cairan amnion. Kendala utama menggunakan sumber DNA dari biopsi villi korialis adalah kemungkinan adanya kontaminasi maternal, oleh karena itu villi korialis perlu dipisahkan terlebih dahulu dari maternal desidua menggunakan mikroskop bedah (dissecting microscope) sebelum dilakukan isolasi DNA fetus. Berdasarkan pertimbangan waktu pelaksanaan, teknik biopsi villi korialis lebih dipilih dibandingkan dengan teknik amniocentesis walaupun memiliki resiko abortus lebih tinggi. Teknik amniocentesis diagnosis prenatal dikerjakan pada trimester kedua sehingga diagnosis baru dapat diketahui pada usia kehamilan yang lebih lanjut. Terminasi pada saat fetus sudah mulai bergerak yakni pada trimester kedua dapat menimbulkan beban emosional yang berat bagi pasien, sehingga diusahakan untuk melakukan diagnosis prenatal pada trimester pertama. ${ }^{2,5]}$

Perkembangan diagnosis prenatal ditujukan untuk keamanan prosedur diagnostik dan ketepatan waktu analisis sehingga diharapkan penegakan diagnosis dapat dilakukan sedini mungkin. Metode amniocentesis dan biopsi villi korealis memiliki resiko membahayakan kesehatan fetus dan maternal, sehingga metode alternatif yang bersifat noninvasif dieksplorasi secara lebih aktif. Penemuan sel fetus, ${ }^{[6]}$ DNA fetus (cff-DNA/cell-free fetal $D N A),{ }^{[7]}$ dan mRNA fetus (cff-mRNA/ fetal messanger $R N A)^{[8]}$ pada sirkulasi maternal memberikan harapan baru untuk diagnosis prenatal noninvasif. Pengambilan sampel fetus tersebut dapat dilakukan lebih dini, yakni sejak usia kehamilan 7 minggu.

Setelah melalui lebih dari tiga dekade penelitian intensif, analisis noninvasif terhadap genom fetus melalui pemeriksaan darah perifer maternal telah menjadi kenyataan, dan telah digunakan oleh beberapa lembaga di Eropa untuk 
mendiagnosis penyakit genetik. ${ }^{[10]}$ Pada artikel ini akan dikaji lebih mendalam mengenai perkembangan diagnosis prenatal nonivasif serta kendala dan potensi penggunaan sel fetus, DNA fetus, dan mRNA fetus untuk mendeteksi penyakit genetik.

\section{Perkembangan Diagnosis Prenatal Noninvasif}

Berbanding terbalik dengan pengetahuan yang mengatakan bahwa plasenta merupakan sawar impermeabel antara ibu dan fetus, beberapa studi membuktikan keberadaan sel fetus, DNA fetus dan mRNA fetus dalam sirkulasi maternal (Gambar 1). ${ }^{[11]}$ Penemuan sel fetus pada sirkulasi maternal pertama kali dilaporkan oleh Schmorl, seorang ahli patologi dari German pada tahun 1893. Schmorl menemukan trofoblas yang berasal dari plasenta pada 17 paru-paru wanita yang meninggal akibat komplikasi eklampsia. ${ }^{[12]}$ Pada tahun 1959, Douglas et al. juga menemukan trofoblas pada sirkulasi maternal menggunakan mikroskop. ${ }^{[13]}$ Perkembangan yang pesat pada bidang diagnosis prenatal noninvasif dimulai sejak Lo et al. mengidentifikasi keberadaan DNA fetus (cff-DNA/ cell free fetal DNA) pada plasma maternal pada tahun 1997. [7] Selanjutnya, mRNA fetus (cff-mRNA) juga ditemukan terdapat dalam plasma maternal oleh Poon et al. pada tahun 2000. ${ }^{[8]}$

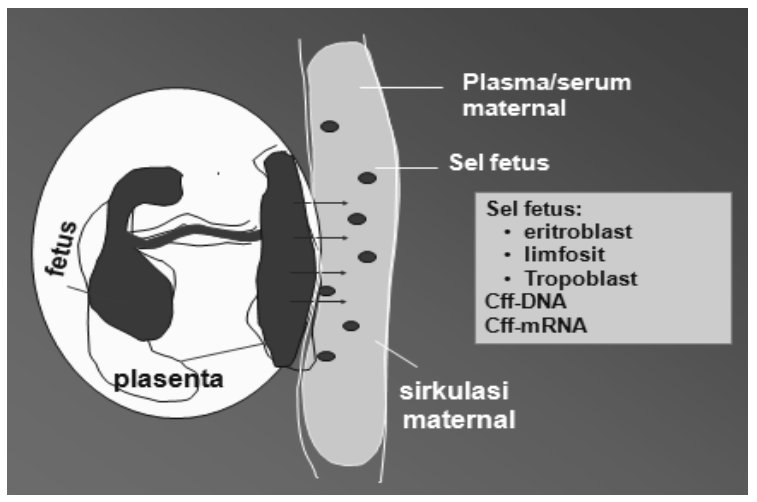

Gambar 1: Sel fetus, DNA dan mRNA fetus pada sirkulasi maternal. Diagnosis prenatal noninvasif dapat dilakukan dengan kehadiran sel fetus, DNA fetus, mRNA fetus pada sirkulasi maternal. DNA dan mRNA fetus yang dideteksi terdapat dalam serum atau plasma maternal (Gambar atas perkenaan Grup Peneliti Kelainan Darah Lembaga Eijkman).

Walaupun keberadaan sel fetus pada sirkulasi maternal sudah diketahui sejak abad ke-19, penggunaan sel fetus tersebut untuk deteksi penyakit genetik belum dapat dilakukan. Selain jumlah sel fetus yang sangat sedikit pada darah maternal, metode khusus juga diperlukan untuk memurnikan sel fetus dari sel-sel lain yang terdapat pada sirkulasi maternal. Penemuan DNA fetus dan mRNA fetus pada sirkulasi maternal yang tanpa memerlukan pengayaan sangat menjanjikan bagi bidang diagnosis prenatal noninvasif penyakit genetik. Keberadaan sekuen spesifik kromosom-Y dalam sirkulasi maternal yang sedang mengandung fetus laki-laki dapat dijadikan marker untuk deteksi penyakit genetik pada fetus. Penyakit genetik yang sudah dapat dideteksi melalui metode ini antara lain penyakit $X$ linked seperti Duchenne muscular dystrophy (DMD) dan penyakit hemofilia. Duchenne muscular dystrophy yaitu penyakit bersifat letal yang menyerang lakilaki karena tidak berfungsinya protein distrofin pada otot. Penyakit hemofilia disebabkan oleh defisiensi faktor VIII yang berperan dalam pembekuan darah. Prinsip kerja metode noninvasif untuk penyakit $X$ linked yaitu dengan cara mendeteksi keberadaan sekuen spesifik kromosom-Y. Jika sekuen spesifik kromosom-Y tidak terdeteksi pada DNA/RNA dalam sirkulasi maternal, diagnosis prenatal dengan cara invasif tidak dibutuhkan untuk konfirmasi. [14] Penggunaan metode noninvasif untuk menentukan jenis kelamin fetus pada kehamilan yang memiliki resiko tinggi penyakit $X$-linked sudah dilakukan di Inggris. Sejak diaplikasikan dari tahun 2006 hingga 2011 terjadi peningkatan penggunaan DNA fetus pada sirkulasi maternal untuk deteksi penyakit ini dari sekitar 50 kasus menjadi lebih dari 400 kasus. ${ }^{[15]}$ Metode ini juga sudah dapat mendeteksi jenis aneuploidi terutama kasus sindrom Down yang disebabkan oleh trisomi kromosom 21. ${ }^{[\mathrm{P} 6]}$

Metode diagnosis prenatal noninvasif juga dilaporkan dapat digunakan untuk 
penentuan jenis kelamin pada kasus ambiguitas seperti congenital adrenal hyperplasia $(\mathrm{CAH})$ yaitu hiperplasia adrenal yang mengakibatkan defisiensi 21hidroksilase. Enzim tersebut berperan dalam jalur normal biosintesis glukokortikoid. Defisiensi 21-hidroksilase menyebabkan akumulasi prekursor glukokortikoid yang akan diubah menjadi androgen. Peningkatan kadar androgen menyebabkan virilisasi genital pada janin wanita dan dapat menimbulkan infertilitas. Pencegahan manifestasi klinis $\mathrm{CAH}$ yang berat dapat dilakukan dengan pemberian dexametason lebih dini bagi janin melalui ibu. $^{[15]}$ Selain itu, keberadaan DNA fetus dapat digunakan untuk mendeteksi penyakit tanatophoric dysplasia yang bersifat letal, diturunkan secara autosomal dominan, dan akibat mutasi de novo. ${ }^{[16,17]}$

Pada penerapannya, analisis materi genetik fetus pada sirkulasi maternal untuk deteksi penyakit genetik memerlukan teknik PCR yang sama dengan pengerjaan DNA fetus yang diperoleh dari amniocentesis dan biopsi villi korialis. Namun terdapat beberapa kendala yang perlu diselesaikan terlebih dahulu sebelum materi genetik fetus pada sirkulasi maternal dapat digunakan sebagai sarana untuk mendeteksi jenis penyakit genetik dengan cakupan yang lebih luas. Salah satu kendala yang perlu diatasi adalah penemuan metode yang efektif untuk memisahkan materi genetik fetus dari materi genetik maternal.

\section{Sel fetus pada sirkulasi maternal}

Pengetahuan mengenai keberadaan sel -sel fetus pada sirkulasi maternal membuka lahan baru untuk diagnosis prenatal noninvasif. Terdapat beberapa jenis sel fetus yang sudah dilaporkan terdapat dalam sirkulasi maternal seperti: trofoblas, leukosit, dan eritrosit fetus berinti (NRBC/ Nucleated Red Blood Cell). Keuntungan menggunakan sel fetus sebagai sumber DNA untuk tes genetik diagnosis prenatal adalah DNA yang diperoleh merupakan DNA murni fetus tanpa perlu menghawatirkan kemungkinan adanya kontaminasi DNA maternal, jika dibanding- kan dengan sampel DNA fetus yang diperoleh dari amnion ataupun biopsi korialis yang memiliki kemungkinan adanya kontaminasi DNA maternal. ${ }^{[12]}$ Keberadaan kedua alel yang berasal dari genom maternal dan paternal pada DNA fetus yang berasal dari sel amnion maupun villi korialis perlu dipastikan terlebih dahulu sebelum dilakukan pendeteksian mutasi untuk menghindari kesalahan diagnosis. Hal ini dilakukan dengan memeriksa variable vumber tandem repeat (VNTR) atau short tandem repeat (STR) sebagai penanda untuk menyingkirkan kemungkinan adanya kontaminasi DNA maternal. ${ }^{[3]}$

Penggunaan sel fetus pada sirkulasi maternal untuk tes diagnostik pelayanan genetik belum rutin dilakukan. Kendala utamanya adalah keberadaan sel fetus yang sangat jarang yaitu satu sel fetus dalam satu mililiter darah maternal. ${ }^{[12]}$ Oleh karena sangat tidak mudah untuk mengisolasi satu sel fetus diantara jutaan sel maternal sehinggga diperlukan suatu pengayaan.

Pada tahun 2002, National Institute of Child Health and Human Development Fetal Cell Isolation Study (NIFTY) berusaha mengatasi masalah ini dengan menggunakan metode magnetic cell sorting (MACS) dan fluorescent-activated cell sorting (FACS) untuk mengisolasi sel fetus. Prinsip dasar kedua teknik tersebut adalah pengenalan antigen-antibodi menggunakan antibodi monoklonal yang spesifik terhadap eritrosit fetus berinti. ${ }^{[12]}$ Kelompok peneliti ini menggunakan antibodi monoklonal untuk mengenali CD71 etritrosit fetus berinti dan melakukan PCR untuk mengamplifikasi sekuen spesifik kromosom -Y. Hasil penelitian menunjukkan sekuen spesifik kromosom-Y terdeteksi hanya pada $75 \%$ wanita yang sedang mengandung janin laki-laki dan kemurnian eritrosit berinti fetus rendah. Kemurnian sel fetus ditingkatkan dengan menggunakan MACS seleksi negatif CD45 untuk mengurangi eritrosit berinti maternal. Prosedur ini dilakukan sebelum mendeteksi eritrosit berinti fetus CD71. Pendeteksian menggunakan MACS menunjukkan hasil yang lebih baik, namun sensitivitas metode 
ini hanya $50 \%{ }^{[13]}$

Setelah isolasi DNA berhasil dilakukan, masih terdapat kendala dalam deteksi mutasi akibat tingginya tingkat allelic drop out. ${ }^{[11]}$ Alellic drop out adalah suatu kondisi dimana salah satu alel tidak dapat diamplifikasi (baik alel maternal ataupun paternal). Hal ini berpotensi menimbulkan negatif palsu jika digunakan sebagai tes genetik. Menurut Hahn et al. minimal dibutuhkan 5-6 sel untuk mengimbangi kemungkinan terjadinya allelic drop out. ${ }^{[10]}$

Kendala lain dalam penggunaan sel fetus pada sirkulasi maternal adalah terjadinya apoptosis pada sel fetus saat memasuki sirkulasi maternal. Hal ini diperkirakan terjadi karena eritroblas fetus memasuki lingkungan yang kaya akan oksigen pada sirkulasi maternal. ${ }^{[11]}$ Walaupun menemui banyak kendala, riset tentang sel fetus ini masih berlangsung. Para ahli berpendapat bahwa riset kedepan lebih ditujukan pada metode isolasi sel fetus dari sirkulasi maternal terlebih dahulu sebelum mencari metode yang relevan untuk ektraksi materi genetik.

\section{DNA Fetus (cff-DNA/cell-free fetal DNA)}

Riset tentang DNA fetus pada serum maternal berkembang setelah ditemukan cell-free tumor DNA pada plasma dan serum pasien kanker. Dasar pemikiran penelitian ini adalah perkembangan fetus dan plasenta yang cepat diumpamakan seperti perkembangan tumor. Lo et al. ${ }^{[7]}$ pada tahun 1997 menemukan keberadaan DNA fetus laki-laki pada plasma dan serum maternal. Amniocentesis dan pengambilan sampel darah perifer dilakukan pada 43 wanita hamil dengan usia kehamilan 12-40 minggu. Melalui amniocentesis diketahui bahwa 30 orang mengandung janin laki-laki dan 13 orang mengandung janin perempuan. DNA fetus diekstraksi dari kedua sampel tersebut, kemudian dilakukan PCR untuk mendeteksi sekuen spesifik kromosom-Y (DYS14). Hasil positif terdeteksi pada 24 dari 30 sampel plasma, dan pada 21 dari 30 sampel serum maternal yang mengandung fetus laki-laki. Hasil ini diperoleh hanya dengan menggunakan $10 \mu \mathrm{L}$ supernatan serum/plasma maternal.

Terdapat beberapa hipotesis mengenai asal DNA fetus dalam sirkulasi maternal antara lain: sel hematopoetik fetus, trofoblas pada plasenta, dan ditransfer secara langsung dari maternal. Pada awalnya DNA fetus diperkirakan berasal dari sel fetus yang berada dalam sirkulasi maternal. Namun mengingat keberadaan sel fetus yang sangat jarang ( 1 sel fetus per $1 \mathrm{~mL}$ darah), tentunya konsentrasi DNA fetus juga akan sangat kecil. Salah satu penjelasan yang dapat diajukan adalah DNA fetus berasal dari sel fetus yang mengalami kerusakan saat mencoba memasuki sirkulasi maternal. Hipotesis lain menyatakan bahwa konsentrasi DNA fetus yang cukup tinggi diperkirakan berasal dari trofoblas plasenta yang mengalami apoptosis, sehingga konsentrasi DNA fetus meningkat seiring dengan perkembangan plasenta pada masa kehamilan. DNA fetus juga dideteksi terdapat pada cairan tubuh maternal lainnya seperti amnion, urin, cairan serebrospinal dan cairan peritoneal. Konsentrasi DNA fetus pada amnion 200 kali lebih banyak dari pada plasma maternal sehingga diperkirakan DNA fetus ditransfer secara langsung dari sirkulasi fetus ke sirkulasi maternal. ${ }^{[11]}$

Menurut Lench et al. Konsentrasi DNA fetus pada serum maternal ditemukan lebih tinggi secara signifikan dibandingkan dengan konsentrasi DNA yang diperoleh dari DNA sel fetus yang diambil dari darah maternal. ${ }^{[15]}$ Pada awal kehamilan, konsentrasi DNA fetus 0,014-0,54\% dalam serum maternal dan 0,39-11,9\% dalam plasma maternal. Konsentrasinya akan bertambah seiiring dengan perkembangan fetus, pada akhir kehamilan konsentrasi DNA fetus $0,032-3,97 \%$ dalam serum maternal dan 2,33-11,4\% dalam plasma.

Prosedur analisis DNA fetus dari serum/plasma maternal lebih mudah daripada analisis DNA dari sel fetus karena tidak memerlukan pengayaan sel fetus. Namun, berdasarkan studi dengan nextgeneration sequencing diketahui bahwa DNA fetus merupakan DNA terfragmentasi 
dengan ukuran sekitar 160bp dan sebagian kecil sekitar 340bp. Hal ini menyebabkan implementasi diagnosis prenatal menggunakan DNA fetus terbatas pada pendeteksian mutasi pada segmen DNA tertentu. Pada pendeteksian mutasi titik pada DNA fetus, perlu didesain primer untuk menghasilkan fragmen DNA yang pendek $(<150 \mathrm{bp})$ agar amplifikasi berjalan dengan efisien. Beberapa jenis penyakit seperti fragile- $X$ syndrome yang disebabkan oleh ekspansi triplet nukleotida (CGG) $\mathrm{n}>1 \mathrm{~kb}$ pada gen FMN1 tidak dapat dideteksi dengan menggunakan metode ini. Pengulangan triplet nukleotida 40-60 kali mungkin masih dapat terdeteksi menggunakan DNA fetus, seperti pada Huntington disease yang disebabkan oleh ekspansi triplet nukleotida (CAG)n pada exon-1 gen $H T T>40$ kali, sedangkan pengulangan triplet nukleotida dengan ukuran lebih besar tidak akan terdeteksi dengan metode ini. ${ }^{[5,15]}$

Chitty et al. ${ }^{[17]}$ melaporkan diagnosis prenatal menggunakan kombinasi USG dan DNA fetus pada kasus tanatophoric dysplasia. Tanatophoric dysplasia adalah penyakit skeletal yang bersifat autosomal dominan dan letal. Pemeriksaan USG pada tiga wanita hamil memperlihatkan ciri-ciri displasia skeletal seperti: fetus sangat pendek, femur melengkung, cloverleaf skull, jari tangan pendek, frontal bossing dan polihidramnion. Lengan pendek mulai dapat terlihat dengan USG sejak 13 minggu masa gestasi.

Hasil pemeriksaan dengan USG ini perlu dikonfirmasi secara molekuler mengingat tampilan klinis ini dapat disebabkan oleh akondroplasia, tanatophoric dysplasia, hipokondroplasia dan displasia akromesomelik. Diagnosis prenatal menggunakan DNA fetus mengkonfirmasi adanya mutasi penyebab tanatophoric dysplasia c.742C $>\mathrm{T}$ (p.Arg248Cys) dan c.1948A $>\mathrm{G}$ (p.Lys650Glu) pada gen fibroblast growth factor receptor 3 (gen FGFR3) pada ketiga sampel tersebut. Diagnosis prenatal menggunakan DNA fetus untuk akondroplasia juga sudah dilakukan, mengingat akondroplasia diturunkan secara autosomal dominan dan 98\% kasus akondroplasia diakibatkan oleh mutasi titik nt1138 G>A (p.Gly380Arg) pada gen FGFR3. ${ }^{[15]}$

Diagnosis prenatal menggunakan DNA fetus terbatas hanya pada mutasi yang diturunkan secara paternal. Keterbatasan ini disebabkan oleh belum adanya teknik untuk memisahkan DNA fetus dengan DNA maternal pada plasma. Teknik elektroforesis pernah dimanfaatkan untuk pengayaan DNA fetus. Ukuran DNA fetus yang lebih pendek dibandingkan dengan DNA maternal memungkinkan dilakukan elektroforesis untuk kemudian DNA fetus tersebut dapat dimurnikan, namun metode ini menyebabkan DNA fetus banyak yang terdegradasi dan terdapat peluang terjadi kontaminasi DNA lain. Penggunaan analisis DNA fetus untuk penyakit genetik yang diturunkan secara autosomal resesif dapat dilakukan dengan adanya teknik digital PCR dan next-gen sequencing. ${ }^{[18]}$ Metode tersebut memungkinkan amplifikasi satu DNA untai ganda dengan cara mempartisi sampel DNA pada ratusan ribu kolom, hasil PCR dianalisis secara kuantitatif dan mutasi pada satu untai DNA dapat dideteksi secara akurat. ${ }^{[10]}$

\section{mRNA Fetus (cff-mRNA/cell-free fetal mRNA)}

Keterbatasan penggunaan DNA fetus pada beberapa kasus membuat penelitian dilakukan untuk mencari alternatif lain. Poon et al. pada tahun 2000 meneliti tentang mRNA fetus pada plasma maternal. [8] Poon et al. mendeteksi keberadaan mRNA $Y$-chromosome-specific zinc finger protein (ZFY) pada semua plasma maternal pada ibu yang mengandung janin laki-laki. Keberadaan mRNA fetus pada sirkulasi maternal sangat tidak terduga mengingat mRNA adalah molekul yang labil dan mudah terdegradasi. Stabilitas mRNA fetus dalam plasma mungkin disebabkan oleh suatu partikel yang mampu melindungi mRNA dari RNAse. ${ }^{[12]}$ 
Keunggulan mRNA fetus dibandingkan dengan DNA fetus adalah dimungkinkannya untuk memperoleh mRNA spesifik plasenta yang tidak diekspresikan pada jaringan maternal. Dasar pemikiran ini adalah jika DNA fetus yang terdapat dalam sirkulasi maternal berasal dari trofoblas, maka kemungkinan mRNA yang diekspresikan secara spesifik pada trofoblas dapat ditemukan dalam sirkulasi maternal. ${ }^{[10]}$ Lo et al. menggunakan gen PLAC4 (placenta specific 4) untuk mendeteksi aneuploidi karena gen ini terletak pada kromosom 21 dan hanya diekspresikan pada plasenta. Analisis mRNA fetus secara kuantitatif dapat digunakan untuk mendeteksi trisomi 21, dengan cara mendeteksi fetus yang memiliki SNP heterozigot pada gen PLAC4 menggunakan mass spectrometry. Transkrip mRNA fetus pada orang normal akan memperlihatkan rasio $1: 1$, sedangkan pada trisomi 21 rasio akan menjadi 2:1. Dari 10 kasus sindrom Down, trisomi 21 pada fetus dapat dideteksi dengan sensitivitas $96 \%$ dan spesifisitas $96 \%$. Kelemahan metode ini adalah tidak semua fetus memiliki SNP heterozigot pada lokus tersebut sehingga memerlukan SNP lain yang dapat dijadikan marker. ${ }^{[18]}$

\section{Potensi pengembangan diagnosis prenatal noninvasif}

Penggunaan sel fetus, DNA fetus, mRNA fetus pada sirkulasi maternal sangat menjanjikan untuk penyakit yang diturunkan secara paternal dan bersifat autosomal dominan pada janin laki-laki. Pada penyakit genetik yang diturunkan secara autosomal resesif pemeriksaan ini sulit dilakukan saat mutasi ayah dan ibu berbeda karena perlu dilakukan pemeriksaan dua jenis mutasi pada janin. Deteksi bahkan lebih sulit pada kasus di mana mutasi ayah dan ibu sama, karena belum ada teknologi yang dapat memisahkan DNA fetus dari DNA maternal dalam plasma/serum. ${ }^{[2]}$ Pendeteksian mutasi jenis autosomal resesif dapat dilakukan untuk mendeteksi mutasi yang diturunkan dari paternal. Jika jenis mutasi autosomal resesif paternal tidak ditemukan pada sampel janin, metode prenatal diagnosis invasif tidak perlu dilakukan. ${ }^{[19]}$ Pendekatan utama berupa pendeteksian keberadaan sekuen spesifik kromosom-Y pada serum/ plasma hanya untuk wanita hamil yang mengandung bayi laki-laki. ${ }^{[20]}$ Penemuan suatu teknik pemisahan DNA fetus dan DNA maternal akan sangat membantu pengembangan diagnosis prenatal noninvasif sehingga dapat digunakan untuk mendeteksi penyakit genetik dengan cakupan jenis penyakit genetik yang lebih luas pada masa mendatang.

Pendekatan lain yang dapat dilakukan seperti analisis pola metilasi janin dan maternal. Metilasi DNA merupakan modifikasi DNA dengan penambahan gugus metil pada basa sitosin terutama pada daerah promoter yang menyebabkan gen tidak dapat diakses faktor transkripsi sehingga tidak dapat diekspresikan. Metilasi DNA disebut perubahan epigenetik karena modifikasi ini tidak menyebabkan perubahan urutan DNA pada gen (sekuen DNA tetap), tetapi mempengaruhi ekspresi gen. ${ }^{[1]}$ Eksplorasi pola metilasi gen lain oleh Chim et al. mendapatkan promoter gen SERPINB5 pada plasenta mengalami hipometilasi sedangkan pada jaringan maternal mengalami hipermetilasi. ${ }^{[21]}$ Perbedaan ini dimanfaatkan untuk mendeteksi trisomi 18 dengan cara mengubah sitosin yang tidak termetilasi menjadi urasil menggunakan bisulfida, sedangkan sitosin yang termetilasi tidak mengalami perubahan. Pada analisis ini, digunakan -156 SNP A/C pada promoter gen SERPINB5. Perbedaan satu basa nukleotida dapat dideteksi dengan mass spectrometry. Pada orang normal yang memiliki dua kromosom 18 akan ditemukan rasio $1: 1$, sedangkan pada trisomi 18 rasio akan menjadi 2:1. Kelemahannya, metode ini hanya dapat mendeteksi trisomi 18 jika SNP yang dijadikan marker pada maternal homozigot $(\mathrm{C} / \mathrm{C})$ sehingga tidak mengganggu analisis. Selain itu, penggunaan bisulfida dapat merusak DNA fetus. 
Kelemahan metode tersebut dapat diminimalkan jika didapatkan marker epigenetik gen yang hipermetilasi pada DNA fetus dan hipometilasi pada DNA maternal sehingga dapat dideteksi dengan enzim restriksi yang sensitif terhadap metilasi, yaitu memotong DNA maternal yang hipometilasi dan meninggalkan DNA fetus yang hipermetilasi. Syarat ini dipenuhi oleh gen RASSFIA yang mengalami hipermetilasi pada janin, sedangkan pada jaringan maternal mengalami hipometilasi. Namun, karena gen RASSF1A terletak pada kromosom 3, maka tidak dapat dijadikan sebagai marker untuk mendeteksi aneuploidi yang relatif umum yaitu pada kromosom 13, kromosom 18 dan kromosom 21. ${ }^{[19]}$

Keberadaan DNA fetus dan mRNA fetus serta riset yang sudah dilakukan selama ini memberikan harapan baru untuk diagnosis prenatal noninvasif. Eksplorasi gen-gen yang dapat dijadikan marker diagnosis penyakit genetik perlu dilakukan agar aplikasi klinis metode diagnosis prenatal noninvasif menggunakan DNA fetus dan mRNA fetus dapat direalisasikan.

\section{SIMPULAN}

Penggunaan metode diagnosis prenatal noninvasif menggunakan DNA dan mRNA fetus mengurangi kebutuhan akan metode invasif secara signifikan. Implementasi penggunaan DNA dan mRNA fetus pada sirkulasi maternal untuk diagnosis prenatal pada beberapa jenis penyakit genetik sudah dapat dilakukan walaupun perkembangannya cukup lambat. Validasi diperlukan agar metode ini dapat diaplikasikan untuk pelayanan tes penyakit genetik dengan cakupan yang lebih luas.

\section{DAFTAR PUSTAKA}

1. Hartwell LH. Genetics: From Genes to Genomes: Mcgraw Hill Companies; 2003.

2. Old J, Henderson S. Molecular diagnostics for haemoglobinopathies. Expert Opin Med Diagn. 2010;4 (3):225-40.
3. Old J, Traeger-Synodinos J, Galanello $\mathrm{R}$, Petrou M, Angastiniotis $\mathrm{M}$. Prevention of Thalassemias and other Hemoglobin Disorder: Thalassemia International Federation; 2004.

4. Leung WC, Leung KY, Lau ET, Tang $\mathrm{MH}$, Chan V. Alpha-thalassaemia. Semin Fetal Neonatal Med. 2008;13 (4):215-22.

5. Harteveld CL, Kleanthous M, Traeger -Synodinos J. Prenatal diagnosis of hemoglobin disorders: present and future strategies. Clin Biochem. 2009;42(18):1767-79.

6. Schmorl G. Pathologisch-anatomische Untersuchungen über PuerperalEklampsie: Vogel; 1893.

7. Lo YM, Corbetta N, Chamberlain PF, Rai V, Sargent IL, Redman CW, et al. Presence of fetal DNA in maternal plasma and serum. Lancet. 1997;350 (9076):485-7.

8. Poon LL, Leung TN, Lau TK, Lo YM. Presence of fetal RNA in maternal plasma. Clin Chem. 2000;46 (11):1832-4.

9. Eason J. Prenatal diagnosis of single gene disorders. Obstet Gynaecol Reprod Med. 2010; 20(5):155-60

10. Hahn S, Zhong XY, Holzgreve W. Recent progress in non-invasive prenatal diagnosis. Semin Fetal Neonatal Med. 2008;13(2):57-62.

11. Bianchi DW. Circulating fetal DNA: its origin and diagnostic potential-a review. Placenta. 2004;25 Suppl A:S93-s101.

12. Litton C, Stone J, Eddleman K, Lee MJ. Noninvasive prenatal diagnosis: past, present, and future. Mt Sinai J Med. 2009; 76(6): 521-8.

13. Purwosunu Y, Sekizawa A, Koide K, Okazaki S, Farina A, Okai T. Clinical potential for noninvasive prenatal diagnosis through detection of fetal cells in maternal blood. Taiwan $\mathrm{J}$ Obstet Gynecol. 2006;45(1):10-20.

14. Bustamante-Aragones A, Rodriguez de Alba M, Perlado S, Trujillo-Tiebas MJ, Arranz JP, Diaz-Recasens J, et al. Non-invasive prenatal diagnosis of 
single-gene disorders from maternal blood. Gene. 2012;504(1):144-9.

15. Lench N, Barrett A, Fielding $\mathrm{S}$, McKay F, Hill M, Jenkins L, et al. The clinical implementation of noninvasive prenatal diagnosis for singlegene disorders: challenges and progress made. Prenat Diagn. 2013;33 (6):555-62.

16. Hill M, Barrett AN, White H, Chitty LS. Uses of cell free fetal DNA in maternal circulation. Best Pract Res Clin Obstet Gynaecol. 2012;26(5):639 -54 .

17. Chitty LS, Khalil A, Barrett AN, Pajkrt E, Griffin DR, Cole TJ. Safe, accurate, prenatal diagnosis of thanatophoric dysplasia using ultrasound and free fetal DNA. Prenat Diagn. 2013;33(5):416-23.
18. Lo YM, Lun FM, Chan KC, Tsui NB, Chong KC, Lau TK, et al. Digital PCR for the molecular detection of fetal chromosomal aneuploidy. Proc Natl Acad Sci U S A. 2007;104 (32):13116-21.

19. Norbury G, Norbury CJ. Non-invasive prenatal diagnosis of single gene disorders: how close are we? Semin Fetal Neonatal Med. 2008;13(2):7683.

20. Lo YM, Chiu RW. Prenatal diagnosis: progress through plasma nucleic acids. Nat Rev Genet. 2007;8(1):71-7.

21. Chim SS, Tong YK, Chiu RW, Lau TK, Leung TN, Chan LY, et al. Detection of the placental epigenetic signature of the maspin gene in maternal plasma. Proc Natl Acad Sci U S A. 2005;102(41):14753-8. 